\title{
The Development of Environmentally Friendly Technologies of Using Coals and Products of Their Enrichment in the Form of Coal Water Slurries
}

\author{
Vasily Murko $^{1 *}$, and Veniamin Hamalainen ${ }^{1}$ \\ ${ }^{1}$ T.F. Gorbachev Kuzbass State Technical University, 650000, 28 Vesennyaya St., Kemerovo, Russia
}

\begin{abstract}
The article presents the current state of the technology for production and combustion of fuel coal water slurries in Russia and foreign countries. Experimental and industrial facilities show the technological and economic efficiency of using this technology for disposal of wastes resulting after coal processing and enrichment. The feasibility studies of use of the technology at large Kuzbass thermal power stations are presented. The possibility of solving a serious environmental problem of reducing storage of the most toxic waste of coal enrichment in the location areas of coal washing plants and coal mining enterprises is demonstrated.
\end{abstract}

\section{Introduction}

The technology of CWF production is one of the most effective technologies for obtaining environmentally friendly and technological fuel. This technology is successfully used in energy industries of a number of foreign countries, although the main developments were carried out in Russia in the middle of the last century. Today, China's energy industry is using this experience successfully [1-8].

There also is a long and successful experience of operating the Emil Gyushe power plant in France, where a project of direct combustion of coal slimes in the form of a suspension in boilers with a circulating fluidized bed has been realized. A complete disposal of coal slimes using this technology at several thermal power stations in the USA has been carried out. The technology for preparation and combustion of CWF obtained both from coal and slimes became a frequent practice in China.

In recent years, the Scientific and Production Enterprise «Sibecotechnika» (Novokuznetsk) has developed this technology in Russia very successfully. Thus, at the turn of the 20th and 21st centuries, technological complexes were developed and implemented both in Russia and abroad.

The purpose of the work is to show the possibilities of wide introduction of the ecologically friendly technology for preparation and combustion of coal and coal slimes in the form of coal water slurries, while solving the problems of resource saving and improving the environmental situation in coal-mining regions.

* Corresponding author: author@email.org 


\section{Results and discussion}

At present, the formulations of effective plasticizer reagents are worked out, which makes it possible to obtain a statically and dynamically stable CWF with the required thermophysical characteristics for direct combustion. To stabilize technological characteristics of the CWF prepared on the basis of fine-dispersed waste of coal enrichment, a technological scheme (figure) has been developed in which the industrial product of the enrichment factory (EF) plays the role of «stabilizer» of the finished fuel ash contents.

The results of industrial testing of the developed technology on the technological complex of OJSC «Mezhdurechye» are given in the work. This technology can be successfully implemented at the EF, enriching coals of coking grades, and which have some difficulties with sale of industrial products. The fact is that its burning by traditional methods (on a grate, in a fluidized bed, etc.) is ineffective. The organization of construction of a mini TPP with production of own cheap electric and heat energy based on combustion of industrial products and filter cake using CWF technology is economically viable.

A vortex combustion system with organization of adiabatic or similar conditions in the boiler has been developed and is successfully used for reliable combustion of coal water slurry fuel, ballasted with moisture and mineral constituents, prepared on the basis of finelydispersed waste and other products of coal enrichment. This technology is currently implemented by «ProEnergoMash» (Barnaul) to burn many local ballasted fuels.

The use of the vortex combustion technology made it possible to successfully carry out several projects with the reconstruction of boilers of small and medium capacity (Table 2).

Table 1. Characteristics of the heat generators operation.

\begin{tabular}{|c|c|c|c|c|c|c|}
\hline \multirow[b]{2}{*}{$\begin{array}{c}\text { Indicator } \\
\text { name }\end{array}$} & \multicolumn{6}{|c|}{ Technological complexes } \\
\hline & $\begin{array}{c}\text { Boiler } \\
\text { house } \\
\text { «Zarechna } \\
\text { ya» mine, } \\
\text { Leninsk- } \\
\text { Kuznetsk }\end{array}$ & $\begin{array}{c}\text { SibUME of } \\
\text { the Russian } \\
\text { Agricultura } \\
\text { I Academy } \\
\text { SD, } \\
\text { Novosibirs } \\
\text { k } \\
\end{array}$ & $\begin{array}{c}\text { Temirta } \\
\text { u, } \\
\text { Kazakh } \\
\text { stan }\end{array}$ & $\begin{array}{l}\text { Mezhdur } \\
\text { echensk }\end{array}$ & $\begin{array}{c}\text { Hanoi, } \\
\text { Vietna } \\
\text { m }\end{array}$ & $\begin{array}{c}\text { Cherepano } \\
\text { vo, } \\
\text { Novosibirs } \\
\text { k region }\end{array}$ \\
\hline $\begin{array}{l}\text { Heating } \\
\text { effciency, } \\
\text { Gcal /h }\end{array}$ & $0.50 \div 0.58$ & 0.25 & $0.3 \div 0.6$ & 4.05 & 1.08 & $0.3 \div 0.6$ \\
\hline $\begin{array}{c}\text { Fuel } \\
\text { consumption, } \\
1 / \mathrm{h}\end{array}$ & $120 \div 130$ & 55 & $\begin{array}{c}110 \div 22 \\
0\end{array}$ & $\begin{array}{l}\text { Up to } \\
1300\end{array}$ & $\begin{array}{c}220 \div 21 \\
0\end{array}$ & $110 \div 220$ \\
\hline $\begin{array}{c}\text { Temperature } \\
\text { in a furnace, } \\
0 \mathrm{C}\end{array}$ & 950 & 950 & $\begin{array}{l}950 \div 10 \\
50\end{array}$ & $\begin{array}{c}1050 \div 115 \\
0\end{array}$ & $\begin{array}{c}1000 \div 1 \\
100\end{array}$ & $950 \div 1050$ \\
\hline
\end{tabular}

However, taking into account, that the amount of finely-dispersed coal enrichment (filter cake) wastes at modern EF ranges from $0.5 \%$ to $10 \%$ of the processing of ordinary coal, and their annual output is from 150 to 1000 tons per year, the use of these wastes in their own boiler houses with a fuel requirement of $\sim 5 \div 15$ thousand tons / year does not solve the problem of their full disposal. Therefore, to use the entire volume of formed coal slimes, it is advisable to burn them in the form of CWF, either at a nearby coal-fired thermal power plant or at the own mini-TPP, to generate electricity and heat. In this case, the industrial product of EF can be effectively used (as shown above). Tables 2-5 provide technical and economic calculations of the use of fine coal enrichment waste at Kuznetsk and Central TPPs of Novokuznetsk, Belovskaya SDPP and mini TPPs with capacities of 1.5 and $10 \mathrm{MW}$. 
Table 2. Technical and economic indicators of the complex for preparation, transportation and combustion of coal water fuel, prepared on the basis of coal enrichment waste of Novokuznetsk EF at Kuznetskaya TPP.

\begin{tabular}{|c|c|c|}
\hline Indicators & Units & CWF \\
\hline Annual production of CWF & thousand $\mathrm{t}$. & 500 \\
\hline Lower calorific value of fuel & $\mathrm{kcal} / \mathrm{kg}$ & 3000 \\
\hline Capital costs, including: & million rubles & 225 \\
\hline $\begin{array}{l}\text { - } \quad \text { CWF preparation workshop } \\
\text { (capacity } 75 \mathrm{t} / \mathrm{h} \text { ) }\end{array}$ & million rubles & 130 \\
\hline $\begin{array}{l}\text { - Transfer of TPP boilers to co-burning of pulverized and } \\
\text { coal water fuel }\end{array}$ & million rub. & 95 \\
\hline CWF cost at TPP & rub./ t & 600 \\
\hline $\begin{array}{l}\text { The cost of fuel for production of } 1 \text { Gcal of thermal } \\
\text { energy }\end{array}$ & rub. & 184 \\
\hline Cumulative economic effect & million rubles / year & 207,5 \\
\hline Payback period of investments & year & $<1,5$ \\
\hline
\end{tabular}

Table 3. Technical and economic indicators using coal slurry fuel, prepared on the basis of coal and coal slimes, by LLC «Central TPP».

\begin{tabular}{|c|c|c|c|c|}
\hline The name of indicators & Units & Coal & $\begin{array}{c}\text { Coal } \\
\text { slimes }\end{array}$ & $\begin{array}{c}\text { Coal } \\
\text { and } \\
\text { coal } \\
\text { slimes }\end{array}$ \\
\hline $\begin{array}{c}\text { Annual capacity of the CWF producing } \\
\text { installation }\end{array}$ & thousand t. & 708 & 383 & 740 \\
\hline Lower calorific value of fuel & kcal / kg & 3600 & 3300 & 3444 \\
\hline Capital costs, including: & million rubles & 430 & 285 & 490 \\
\hline The cost price of slurry fuel & million rubles & 1134 & 738,5 & 858 \\
\hline $\begin{array}{c}\text { The cost of fuel for production of 1 Gcal } \\
\text { of energy (70\% -CWF + 30\% -gas) }\end{array}$ & million rub. & 371 & 214 & 440 \\
\hline
\end{tabular}

Table 4. Technical and economic indicators using coal slurry fuel, prepared on the basis of filter cake and coal slimes, by EF «SUEK-Kuzbass» at Belovskaya SDPP (1 block of the PK-40 boiler).

\begin{tabular}{|c|c|c|}
\hline Indicators & Units & CWF \\
\hline The annual CWF demand & thousand t. & 92,4 \\
\hline $\begin{array}{c}\text { Share of CWF in the fuel balance of the boiler } \\
\text { block }\end{array}$ & $\%$ & 20 \\
\hline Lower calorific value of fuel & $\mathrm{kcal} / \mathrm{kg}$ & 3200 \\
\hline
\end{tabular}




\begin{tabular}{|c|c|c|}
\hline Capital costs, including: & million rubles & 40,5 \\
\hline CWF cost at SDPP & rub./t & 500 \\
\hline $\begin{array}{c}\text { The cost of fuel for production of 1 Gcal of thermal } \\
\text { energy }\end{array}$ & rub. & 184 \\
\hline Cumulative economic effect & million rubles / year & 30,2 \\
\hline Payback period of investments & year & $<1,5$ \\
\hline
\end{tabular}

Table 5. Economic indicators of technological complexes (mini TPP).

\begin{tabular}{|c|c|c|c|}
\hline \multirow{2}{*}{ Indicators } & \multicolumn{3}{|c|}{ Electric power, MWh } \\
\cline { 2 - 4 } & 1,0 & 5,0 & 10,0 \\
\hline The cost price of fuel, rubles / t & 300 & 270 & 250 \\
\hline $\begin{array}{c}\text { The cost price of the produced electric energy, } \\
\text { rubles / kWh }\end{array}$ & 0,95 & 0,80 & 0,70 \\
\hline Cost of electrical energy, rub. / kWh & 2,50 & 2,50 & 2,50 \\
\hline $\begin{array}{c}\text { The economic effect of generating 1 kWh, rubles / } \\
\text { kWh }\end{array}$ & 1,55 & 1,70 & 1,80 \\
\hline Capital costs, mln. rub. & 96 & 400 & 640 \\
\hline Payback period, year & 5 & 4 & 3,5 \\
\hline
\end{tabular}

\section{Conclusion}

The technology of production and combustion of coal water slurry fuel in boilers of different capacity is being developed in many countries. Experimental and industrial tests showed that the biggest economic efficiency and the essential environmental effect are reached using WCF, produced from coal slimes. In this case the serious problem of disposal of the most toxic finely-dispersed wastes of coal enrichment is solved, as their storage requires large place in the areas of coal mining and conversion.

\section{References}

1. V. Murko, A. Djundubaev, M. Baranova, A. Biibosunov, V. Kulagin, Hydrotransport fuel and energy complexes. The Russian-Kyrgyz scientific and technical cooperation in the field of power engineering, 250 (Krasnoyarsk, Sib. Feder. University, 2015)

2. V. Biletskyy, P. Sergeyev, O. Krut, Mining of Mineral Deposits, 45, 105 (2013)

3. S. Mochalov, I. Rybenko, L. Ermakova. World Applied Sciences Journal, 19:1, 20 (2012)

4. A. Kijo-Kleczkowska,. Archives of Thermodynamics, 32:1, 45 (2011)

5. A. Kijo-Kleczkowska, Fuel, 90:2, 865 (2011)

6. E. Karpov. Ecological systems, 1, (2008) 
7. F. Serant, A. Tsepenuk, Yu. Ovchinnikov, S. Luschenko, E. Karpov, Collection of scholarly articles "Modern science", 1:6, 95 (2011)

8. O. Nosko, Coal water fuel - environmentally friendly and efficient. (News of the Siberian science. IT SB RAS, 2016) 
